Part of Journal of Research of the National Bureau of Standards, Volume 15, September 1935

\title{
HEATS OF VAPORIZATION OF EIGHT GASOLINES
}

\author{
By Ralph S. Jessup
}

\section{ABSTRACT}

Measurements of the heats of vaporization at $40^{\circ} \mathrm{C}$ of 8 gasolines were made with an estimated accuracy of about 3 percent. The fuels investigated included 1 natural gasoline, 2 aviation gasolines, 1 straight run naphtha, 3 cracked naphthas, and 1 "safety fuel." The last named fuel is a hydrogenation product, which is apparently richer in hydrocarbons of the aromatic series than the other fuels. The results on all the fuels, except the safety fuel, can be represented within the accuracy of the measurements by a linear function of either specific gravity or average volatility.

The application of the results to the problem of ice formation in the carburetors of aviation engines due to cooling produced by evaporation of the fuel is briefly discussed. It is concluded that large differences in the rates of formation of ice with different fuels cannot be attributed to differences in the heats of vaporization, but must be largely due to differences in the completeness of vaporization of the fuels in the carburetor, resulting from differences in volatility of the fuels.

\section{CONTENTS}

I. Introduction

II. Apparatus and method

III. Measurements on fuels

1. Materials investigated

2. Results of measurements

\section{INTRODUCTION}

The work described in this paper was undertaken to obtain data on the heats of vaporization of fuels used in automobile and aircraft engines. Such data are of importance in the analysis of engine performance, and also in connection with the problem of ice formation in the carburetor, resulting from the cooling produced by evaporation of the fuel. ${ }^{1}$ Most previous measurements of the heats of vaporization of petroleum products have been made at relatively high temperatures, and values obtained by extrapolating the results of various observers to lower temperatures are not in satisfactory agreement.

\section{APPARATUS AND METHOD}

The method used consisted essentially in vaporizing a known mass of the fuel in a stream of air flowing through a coil of tubing immersed in the water of a calorimeter, and measuring the resulting change in temperature of the calorimeter. The heat of vaporization is then given by

$$
L=\frac{C \Delta \theta}{m}
$$

\footnotetext{
+ Allen, Rodgers, and Brooks, Soc. Automotive Engrs. J. 35, 417 (1934).
} 
where $C$ is the heat capacity of the calorimeter, $\Delta \theta$ is the temperature change of the calorimeter corrected for heat transfer between the calorimeter and its surroundings, and $m$ is the mass of fuel evaporated.

The apparatus is shown schematically in figure 1 . The vaporizing coil V is made of copper tubing $7 / 16$ inch in outside diameter and 12

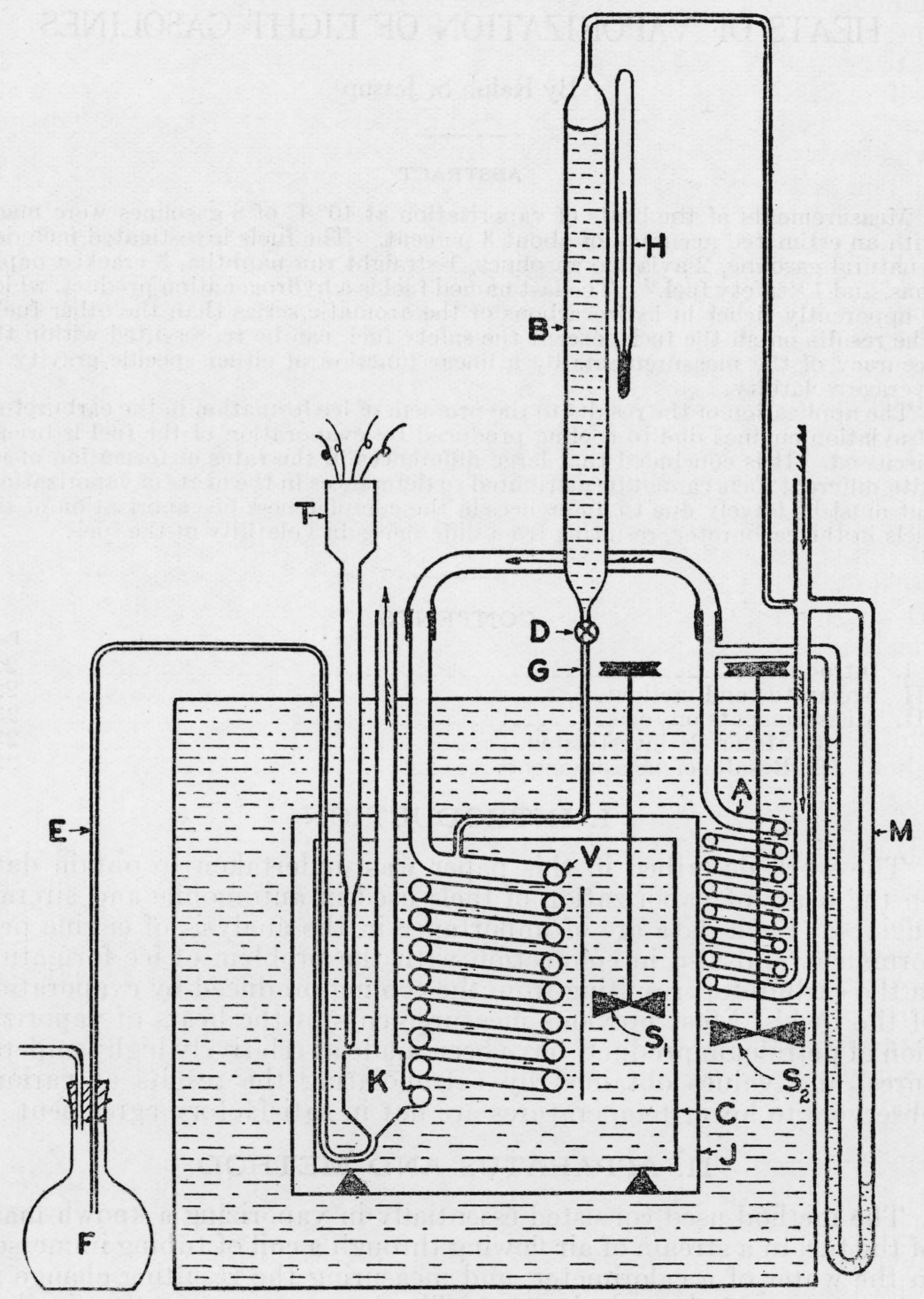

Figure 1.-Schematic diagram of apparatus.

feet long. It was immersed in the water contained in the calorimeter vessel C, which was completely inclosed by the jacket J. The jacket and calorimeter were separated at all points by a 1-cm air space.

The temperature of the jacket was kept constant within about $0,01^{\circ} \mathrm{C}$ by means of a thermo-regulator. The temperature of the 
calorimeter was measured by means of the platinum resistance thermometer $\mathrm{T}$. The serew propellors $\mathrm{S}_{1}$ and $\mathrm{S}_{2}$ were used to stir the water in calorimeter and jacket, respectively. The calorimeter and jacket have been described previously. ${ }^{2}$

A stream of air flowed first through the coil of copper tubing A immersed in the jacket water, and then through a rubber tube to the vaporizing coil $\mathrm{V}$. The manometer $\mathrm{M}$ was used to indicate the rate of flow of the air.

The fuel to be vaporized was contained in the $25 \mathrm{ml}$ burette B, and flowed to the vaporizing coil V through a small copper tube which was soldered to the jacket wall for a distance of about 17 inches.

The heat capacity of the calorimetric system was calculated from the masses and specific heats of the water and metal parts (mostly copper). The value used for the specific heat of water at $40^{\circ} \mathrm{C}$ is 4.173 international joules per gram degree C. ${ }^{3}$ The calculated heat capacity of the calorimeter was 13,950 international joules per degree C. This value was checked experimentally by measurements of the heat of vaporization of water, the results of which are summarized in table 1 .

The procedure in making a measurement of heat of vaporization of a fuel was as follows: The temperature of the calorimeter was adjusted to approximate equality with that of the jacket, and the flow of air through the vaporizing coil was started. The burette $B$ (fig. 1) was filled with the fuel, and enough of this fuel was allowed to flow into the tube $\mathrm{G}$ to fill it completely, after which the valve $D$ was closed. After sufficient time had elapsed for the establishment of a steady state, the position of the liquid meniscus in B, and the temperature indicated by the mercurial thermometer $\mathrm{H}$ were observed. From this time to the end of the experiment a reading of the temperature of the calorimeter was made each minute. After about 10 minutes of such observations the valve $D$ was opened, allowing the fuel to flow to the vaporizer. When the liquid meniscus in the burette reached the lowest graduation the valve $\mathrm{D}$ was again closed. Any unevaporated residue which reached the chamber $K$ was from time to time drawn through the tube $\mathrm{E}$ into the flask $\mathrm{F}$ and, after the completion of the experiment, was weighed. The observations of the temperature of the calorimeter were continued from 10 to 20 minutes after the time-temperature curve indicated that no more fuel was being evaporated. The mass of the fuel evaporated was calculated from the volume of fuel delivered to the vaporizer as measured by means of the burette, the density of the fuel, and the mass of the unevaporated residue.

The correction for heat transfer between the calorimeter and its surroundings was calculated from the observed rates of change of the temperature of the calorimeter at the beginning and end of the experiment when air was flowing through the vaporizing coil but no fuel was being evaporated. In making this calculation it was assumed that the rate of transfer of heat was a linear function of the calorimeter temperature. The heat transfer calculated in this way includes the heat transfer between the calorimeter and the stream of air flowing through the vaporizing coil.

\footnotetext{
2 Bul. BS 11, 189 (1914) S230. J. Research NBS 13, 469 (1934) RP721,

3 Int. Crit. Tables 5, 113.
} 
A correction was applied to the results to take account of the fact that the fuel entered the calorimeter at a temperature different from; that of the calorimeter. This correction was calculated using specific heat data given at Cragoe ${ }^{4}$ and assuming that the fuel entered the calorimeter at the temperature of the jacket and was cooled to the average of the initial and final temperatures of the calorimeter.

The total temperature change of the calorimeter in the measurements of heats of vaporization of gasolines ranged from 0.4 to $1.0^{\circ} \mathrm{C}$. The corrected temperature change ranged from about 50 percent of the total for the least volatile fuel to about 95 percent of the total for the most volatile fuel. The time during which evaporation of a fuel was taking place varied from 10 to 100 minutes.

As a test of the accuracy attainable with the apparatus, measurements were made of the heats of vaporization of water and of benzene. The water used in these experiments was ordinary distilled water, and the benzene was of "reagent" grade obtained commercially, and was not further purified. The results on water are compared in table 1 with data reported by Osborne, Stimson, and Fiock, ${ }^{5}$ and the results on benzene are compared in table 2 with data reported by Fiock, Ginnings, and Holton. ${ }^{6}$ In the present measurements the rate of flow of liquid to the vaporizing coil was varied over a considerable range in order to determine whether the results were affected by such variation.

TABLE 1.-Comparison of data on water with data reported by Osborne, Stimson, and Fiock

\begin{tabular}{|c|c|c|c|c|c|}
\hline \multirow[b]{2}{*}{ Experiment } & \multirow{2}{*}{$\begin{array}{l}\text { Mean tem- } \\
\text { perature }\end{array}$} & \multirow{2}{*}{$\begin{array}{c}\text { Percentage } \\
\text { evaporated } \\
\text { in present } \\
\text { work }\end{array}$} & \multicolumn{2}{|c|}{ Heat of vaporization } & \multirow[b]{2}{*}{ Difference } \\
\hline & & & $\begin{array}{l}\text { Present } \\
\text { work }\end{array}$ & $\begin{array}{c}\text { Osborne, } \\
\text { Stimson, } \\
\text { and } \\
\text { Fiock }\end{array}$ & \\
\hline 1 & $\begin{array}{r}{ }^{\circ} \mathrm{C} \\
38.8 \\
38.1 \\
38.0\end{array}$ & $\begin{array}{l}56 \\
86 \\
96\end{array}$ & $\begin{array}{r}\text { int. } \mathrm{j} / \mathrm{g} \\
2,413 \\
2,416 \\
2,420\end{array}$ & $\begin{array}{r}\text { int. } \mathbf{j} / \mathrm{g} \\
2,408 \\
2,409 \\
2,410\end{array}$ & $\begin{array}{r}\text { Percent } \\
+0.2 \\
+.3 \\
+.4\end{array}$ \\
\hline
\end{tabular}

TABLE 2.-Comparison of data on benzene with data reported by Fiock, Ginnings, and Holton

\begin{tabular}{|c|c|c|c|c|c|}
\hline \multirow[b]{2}{*}{ Experiment } & \multirow[b]{2}{*}{$\begin{array}{l}\text { Mean tem- } \\
\text { perature }\end{array}$} & \multirow{2}{*}{$\begin{array}{l}\text { Rate of } \\
\text { vaporiza- } \\
\text { tion in } \\
\text { present } \\
\text { work }\end{array}$} & \multicolumn{2}{|c|}{ Heat of vaporization } & \multirow[b]{2}{*}{ Difference } \\
\hline & & & $\begin{array}{l}\text { Present } \\
\text { work }\end{array}$ & $\begin{array}{l}\text { Fiock, } \\
\text { Ginnings, } \\
\text { and } \\
\text { Holton }\end{array}$ & \\
\hline $\begin{array}{l}1 \\
2 \\
3 \\
4 \\
5 \\
6 \\
6\end{array}$ & $\begin{array}{l}{ }^{\circ} \mathrm{C} \\
39.7 \\
39.6 \\
39.7 \\
40.4 \\
39.6 \\
40.0 \\
39.8\end{array}$ & $\begin{array}{r}\mathrm{g} / \mathrm{min} \\
0.5 \\
.9 \\
1.1 \\
1.6 \\
2.1 \\
.6 \\
.5\end{array}$ & $\begin{array}{r}\text { int. } \mathrm{j} / \mathrm{g} \\
428.2 \\
425.8 \\
424.8 \\
424.6 \\
424.7 \\
417.8 \\
421.5\end{array}$ & $\begin{array}{r}\text { int. } \mathrm{j} / \mathrm{g} \\
422.3 \\
422.4 \\
422.3 \\
421.9 \\
422.4 \\
422.1 \\
422.1\end{array}$ & $\begin{array}{r}\text { Percent } \\
+1.4 \\
+.8 \\
+.6 \\
+.6 \\
+.6 \\
-1.0 \\
-.1\end{array}$ \\
\hline
\end{tabular}

${ }^{4}$ Misc. Pub. BS 97 (1929).

5 BS J. Research 5, 411 (1930) RP209.

6 BS J. Research 6, 881 (1931) RP312. 
Evaporation was not complete in any of the experiments on water, and a different percentage of the water was evaporated for each rate of flow. The benzene, on the other hand, was completely evaporated in every experiment, the different rates of flow resulting merely in different rates of evaporation. It is seen from tables 1 and 2 that, within the precision of the measurements, there is no systematic variation of observed heat of vaporization with percentage of liquid evaporated or with rate of flow of liquid to the vaporizer. The results obtained on water are higher than those reported by Osborne, Stimson, and Fiock by 0.3 percent on the average, while the results on benzene are higher than those reported by Fiock, Ginnings, and Holton by 0.4 percent.

\section{MEASUREMENTS ON FUELS}

\section{MATERIALS INVESTIGATED}

The fuels on which measurements were made are listed in table 3 , in which are also given for each material the source if known, ASTM distillation data, specific gravity, index of refraction, and average volatility. Average volatility is defined as the average of the three temperatures at which 10,50 , and 90 percent of the fuel was evaporated in the ASTM distillation test (percentage evaporated=percentage distilled, plus evaporation loss). The range of volatilities of the samples is somewhat wider than that of marketed gasolines. This fact was expected to result in a more definite indication of any variation of heat of vaporization with volatility.

TABLE 3.-Description of samples

\begin{tabular}{|c|c|c|c|c|c|c|c|c|c|c|c|c|c|c|c|}
\hline \multirow[b]{2}{*}{ 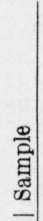 } & \multirow[b]{2}{*}{ Material } & \multirow[b]{2}{*}{ Source } & \multirow{2}{*}{$\begin{array}{l}\text { Cracking } \\
\text { process }\end{array}$} & \multicolumn{10}{|c|}{ ASTM distillation data- } & \multirow{2}{*}{ 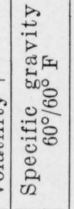 } & \multirow{2}{*}{ 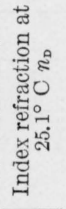 } \\
\hline & & & & 氶 & $\cong 0$ & ఫ్లి & 은 & , & \&̊ & 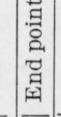 & $\begin{array}{l}0 \\
0 \\
0 \\
\end{array}$ & 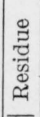 & & & \\
\hline & & & & ${ }^{\circ} \mathrm{C}$ & ${ }^{\circ} \mathrm{C}$ & ${ }^{\circ} \mathrm{C}$ & ${ }^{\circ} \mathrm{C}$ & ${ }^{\circ} \mathrm{C}$ & ${ }^{\circ} \mathrm{C}$ & ${ }^{\circ} \mathrm{C}$ & $\%$ & $\%$ & ${ }^{\circ} \mathrm{C}$ & & \\
\hline 1 & $\begin{array}{l}\text { Natural } \\
\text { Aviation }\end{array}$ & Oklah & & $\begin{array}{l}36 \\
55\end{array}$ & $\begin{array}{l}45 \\
65\end{array}$ & 52 & 61 & 78 & 104 & $5\left|\begin{array}{l}147 \\
5115\end{array}\right|$ & $\left|\begin{array}{l}1.0 \\
1.4\end{array}\right|$ & 0.9 & 69 & $|0.675|$ & 1. 3776 \\
\hline & & & & & 67 & 78 & 87 & 95 & 108 & 143 & 1. 0 & & 86 & .729 & 1. $404_{1}$ \\
\hline & $\begin{array}{l}\text { Straight-run } \\
\text { naphtha. }\end{array}$ & $\begin{array}{l}\text { Los Angeles } \\
\text { basin. }\end{array}$ & & 60 & 98 & 122 & 141 & 161 & 194 & $|222|$ & . & 1.2 & 143 & $\mid .773$ & 1.42 \\
\hline $\mathbf{5}$ & $\begin{array}{l}\text { Cracked naphtha, } \\
100 \% \text {. }\end{array}$ & & Cross_ & & 107 & 142 & 169 & 193 & 212 & 224 & & 1.1 & 162 & .789 & 1. 437 \\
\hline & 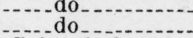 & Oklahoma... & Doherty - & $\begin{array}{l}46 \\
49\end{array}$ & $\mid \begin{array}{l}78 \\
83\end{array}$ & $\begin{array}{l}110 \\
122\end{array}$ & $\mid \begin{array}{l}152 \\
152\end{array}$ & $\begin{array}{l}1755 \\
176\end{array}$ & $\mid \begin{array}{l}184 \\
205\end{array}$ & 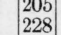 & 1.17 & $\begin{array}{r}.9 \\
13\end{array}$ & $\begin{array}{l}130 \\
145\end{array}$ & $\mid \begin{array}{r}.748 \\
.760\end{array}$ & $\begin{array}{l}\text { 1. } 4143 \\
\text { 1. } 424\end{array}$ \\
\hline 8 & Safety fuel. . & & & 156 & 165 & & 175.5 & 181.5 & 191.5 & 5205 & .2 & 1.1 & 177 & .874 & 1. $492_{4}$ \\
\hline
\end{tabular}

The safety fuel (sample 8) is a hydrogenation product and differs considerably in some of its properties from the other fuels investigated. The heat of vaporization (fig. 2 and 3), heat of combustion, ${ }^{7}$ and refractive index (table 3) of this fuel all indicate that it is richer in aromatic hydrocarbons than the other fuels listed in table 3. Aromatic constituents were also indicated by the following chemical tests. A sample of the fuel was examined for unsaturated hydrocarbons (olefins) by warming it with a solution of iodine in carbon

7 Measured in this laboratory and found to be 10,400 calories per gram, as compared with values ranging from 10,000 to $\mathbf{1 0 , 5 0 0}$ calories per gram for the liquid aromatic hydrocarbons (Int. Crit. Tables $\mathbf{5}$, 162). 
tetrachloride. The color of the iodine solution did not fade, indicating the absence of unsaturated constituents. A sample of the fuel was then treated with a mixture of fuming nitric and sulphuric acids in a vessel which was kept cool by running tap water over the outside. The fuel was almost entirely converted into nitro derivatives which, when poured on ice, partially froze to a yellow solid. This behavior is characteristic of aromatic compounds, and it appears probable that the fuel is composed largely of aromatic constituents. Copious evolution of brown $\mathrm{NO}_{2}$ fumes during the nitration indicated that a portion of the fuel was oxidized rather than nitrated, and this portion may have been nonaromatic material.

\section{RESULTS OF MEASUREMENTS}

The results of the measurements on the various fuels are given in table 4. In none of the individual experiments did the average templerature of the calorimeter differ from $40^{\circ} \mathrm{C}\left(104^{\circ} \mathrm{F}\right)$ by more than $0.8^{\circ} \mathrm{C}$, and in no case did the average temperature in all the experiments on any one fuel differ from $40^{\circ} \mathrm{C}$ by more than $0.3^{\circ} \mathrm{C}$. Since the heats of vaporization of these materials change by only about 0.1 or 0.2 percent per degree $\mathrm{C}$, the average values given in table 4 may, within the limits of experimental error, be taken as the heats of vaporization of the fuels at $40^{\circ} \mathrm{C}$.

TABLE 4.-Results of measurements

SAMPLE

\begin{tabular}{|c|c|c|c|c|}
\hline Experiment & $\begin{array}{l}\text { Rate of } \\
\text { flow of } \\
\text { liquid } \\
\text { to va- } \\
\text { porizer }\end{array}$ & $\begin{array}{c}\text { Per- } \\
\text { centage } \\
\text { evapo- } \\
\text { rated }\end{array}$ & $\begin{array}{c}\text { Heat } \\
\text { of va- } \\
\text { poriza- } \\
\text { tion }\end{array}$ & $\begin{array}{c}\text { Per- } \\
\text { centage } \\
\text { devia- } \\
\text { tion } \\
\text { from } \\
\text { mean }\end{array}$ \\
\hline & $\mathrm{g} / \mathrm{min}$ & & int. $\mathrm{j} / \mathrm{g}$ & \\
\hline $\begin{array}{l}1 \\
2-\cdots \\
3 \\
4 \\
4\end{array}$ & $\begin{array}{r}0.8 \\
1.1 \\
2.2 \\
.6\end{array}$ & $\begin{array}{l}100 \\
100 \\
100 \\
100\end{array}$ & $\begin{array}{l}350 \\
351 \\
354 \\
346\end{array}$ & $\begin{array}{r}0.0 \\
+.3 \\
+1.1 \\
-1.1\end{array}$ \\
\hline Mear & & 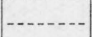 & 350 & \pm .6 \\
\hline
\end{tabular}

SAMPLE 2

\begin{tabular}{c|c|c|c|c}
\hline 1 & 0.9 & 100 & 349 & -0.3 \\
2 & 1.1 & 100 & 351 & +.3 \\
3 & 1.4 & 100 & 350 & 0 \\
\hline & & & 350 & \pm .2 \\
\hline
\end{tabular}

\begin{tabular}{l|r|r|r|r}
\hline \multicolumn{5}{c}{ SAMPLE 3 } \\
\hline $1 \ldots \ldots$ & 1.3 & 100 & 352 & 0.0 \\
\hline $3 \ldots$ & 1.0 & 100 & 353 & \pm .3 \\
\hline Mean & 1.9 & 100 & 351 & -.3 \\
\hline & & & & \\
\hline
\end{tabular}

SAMPLE 4

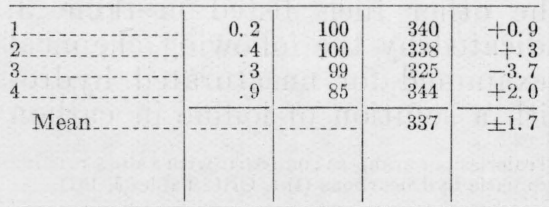

SAMPLE 5

\begin{tabular}{|c|c|c|c|c|}
\hline Experiment & $\begin{array}{c}\text { Rate of } \\
\text { flow of } \\
\text { liquid } \\
\text { to va- } \\
\text { porizer }\end{array}$ & $\begin{array}{c}\text { Per } \\
\text { centage } \\
\text { evapo- } \\
\text { rated }\end{array}$ & $\begin{array}{c}\text { Heat } \\
\text { of va- } \\
\text { poriza- } \\
\text { tion }\end{array}$ & $\begin{array}{l}\text { Per- } \\
\text { centage } \\
\text { devia- } \\
\text { tion } \\
\text { from } \\
\text { mean }\end{array}$ \\
\hline & $\mathrm{g} / \mathrm{min}$ & & int. $\mathrm{j} / \mathrm{g}$ & \\
\hline $\begin{array}{l}1 \\
2 \\
3 \\
4 \\
4\end{array}$ & $\begin{array}{l}0.75 \\
.7 \\
.15 \\
.4\end{array}$ & $\begin{array}{l}66 \\
65 \\
95 \\
77 \\
\end{array}$ & $\begin{array}{l}326 \\
311 \\
310 \\
321 \\
\end{array}$ & $\begin{array}{l}+2.8 \\
-1.9 \\
-2.2 \\
+1.3\end{array}$ \\
\hline Mean. & - & ......... & 317 & \pm 2.0 \\
\hline \multicolumn{5}{|c|}{ SAMPLE 6} \\
\hline $\begin{array}{l}1 \\
2 \\
3\end{array}$ & $\begin{array}{r}0.6 \\
.8 \\
.4 \\
\end{array}$ & $\begin{array}{c}100 \\
99 \\
99.8 \\
\end{array}$ & $\begin{array}{l}324 \\
320 \\
334 \\
\end{array}$ & $\begin{array}{r}-0.6 \\
-1.8 \\
+2.5 \\
\end{array}$ \\
\hline Mean & (n) & $\mid$ & 326 & \pm 1.6 \\
\hline \multicolumn{5}{|c|}{ SAMPLE 7} \\
\hline $\begin{array}{l}1 \ldots \ldots \\
2 \ldots \ldots \\
3 \ldots \ldots \\
4 \ldots \ldots \\
5 \ldots \ldots \\
6 \ldots \ldots\end{array}$ & \begin{tabular}{c|}
0.5 \\
.2 \\
.35 \\
1.1 \\
.4 \\
.4 \\
\end{tabular} & \begin{tabular}{l|}
87 \\
99.5 \\
93 \\
65 \\
87 \\
86 \\
\end{tabular} & $\begin{array}{l}316 \\
323 \\
333 \\
348 \\
334 \\
335 \\
\end{array}$ & $\begin{array}{r}-4.7 \\
-2.6 \\
+.5 \\
+5.0 \\
+.8 \\
+1.1 \\
\end{array}$ \\
\hline Mean.. & $\ldots$ & $\ldots$ & $331_{5}$ & \pm 2.4 \\
\hline \multicolumn{5}{|c|}{ SAMPLE 8} \\
\hline $\begin{array}{l}1 \ldots \\
2 \ldots \\
3 \\
4 \ldots \\
5 \\
6 \\
7 \\
7 \ldots\end{array}$ & $\begin{array}{l}0.2 \\
.9 \\
.25 \\
.5 \\
1.2 \\
.6 \\
.35 \\
\end{array}$ & $\begin{array}{l}98 \\
45 \\
92 \\
63 \\
37.5 \\
63 \\
78 \\
\end{array}$ & $\begin{array}{l}370 \\
382 \\
380 \\
365 \\
378 \\
362 \\
376 \\
\end{array}$ & $\begin{array}{r}-0.8 \\
+2.4 \\
+1.9 \\
-2.1 \\
+1.3 \\
-3.0 \\
+.8\end{array}$ \\
\hline Mean. & . & 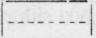 & 373 & \pm 1.8 \\
\hline
\end{tabular}


There are two possible systematic errors in the results obtained from experiments in which the fuel was only partially evaporated. One of these errors results from the fact that the evaporated portion is richer than the original fuel in the more volatile constituents. The other error may arise from the failure of a small amount of the unevaporated residue to drain out of the chamber $K$ (fig. 1), resulting in an error in the value used for the mass of fuel evaporated. These two errors are of opposite sign, and the fact that the data of table 4 do not show any systematic variation of observed heat of vaporization with percentage of fuel evaporated indicates that their combined effect is negligible in comparison with the accidental errors.

It is seen from table 4 that fair precision was attained in the measurements on samples 1,2 , and 3 , which were sufficiently volatile so that they could be completely vaporized in relatively short times.

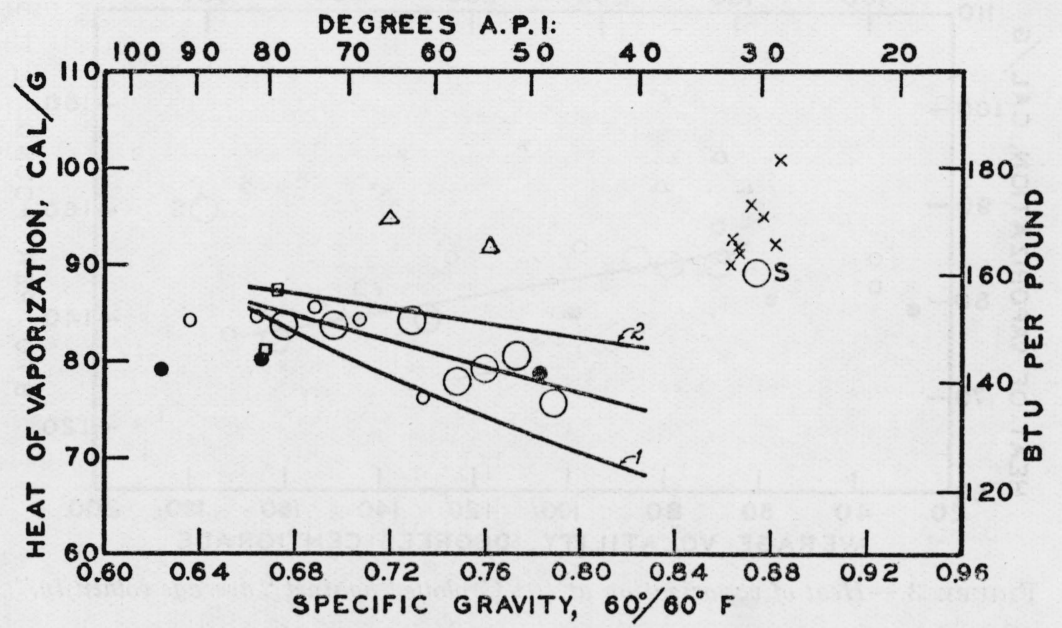

Figure 2.- Heat of vaporization at $40^{\circ} \mathrm{C}$ plotted against specific gravity.

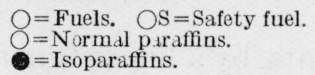

$\square=$ Olefins.

$\triangle=$ Naphthenes.

$\mathrm{X}=$ Aromatics.

For the remaining samples, which were considerably less volatile, the precision was not so high, the average deviation from the means being of the order of 2 percent and the maximum deviation 5 percent.

Lower precision in the measurements on the less volatile fuels is to be expected because, for a fuel of low volatility, the time required to vaporize a large fraction of the sample was so long that the change in temperature of the calorimeter due to heat interchange with its surroundings was of the same order of magnitude as the change in temperature produced by evaporation of the fuel. Consequently, the error in the value obtained for the heat of vaporization of the fuel resulting from error in the correction for heat transfer was of the same order of magnitude as the error in this correction. The error in this correction was greater in the present measurements than in many calorimetric experiments, because a large part of the heat transfer was between the calorimeter and the stream of air flowing through the vaporizer, and this heat transfer was affected by changes in room temperature and changes in the rate of flow of air, neither 
of which was entirely constant. Decreasing the correction for heat transfer by shortening the time of the experiment resulted in a smaller fraction of the sample being evaporated, with a consequent reduction in the temperature change of the calorimeter, and in the precision with which this temperature change could be measured. The precision of measurement of the mass of fuel evaporated was also lower when a small fraction of the fuel was evaporated than when a large fraction was evaporated.

The results are shown graphically in figures 2 and 3 , where heat of vaporization is plotted against specific gravity and average volatility, respectively. It is seen from these figures that the data on all the fuels, with the exception of the safety fuel, may be represented,

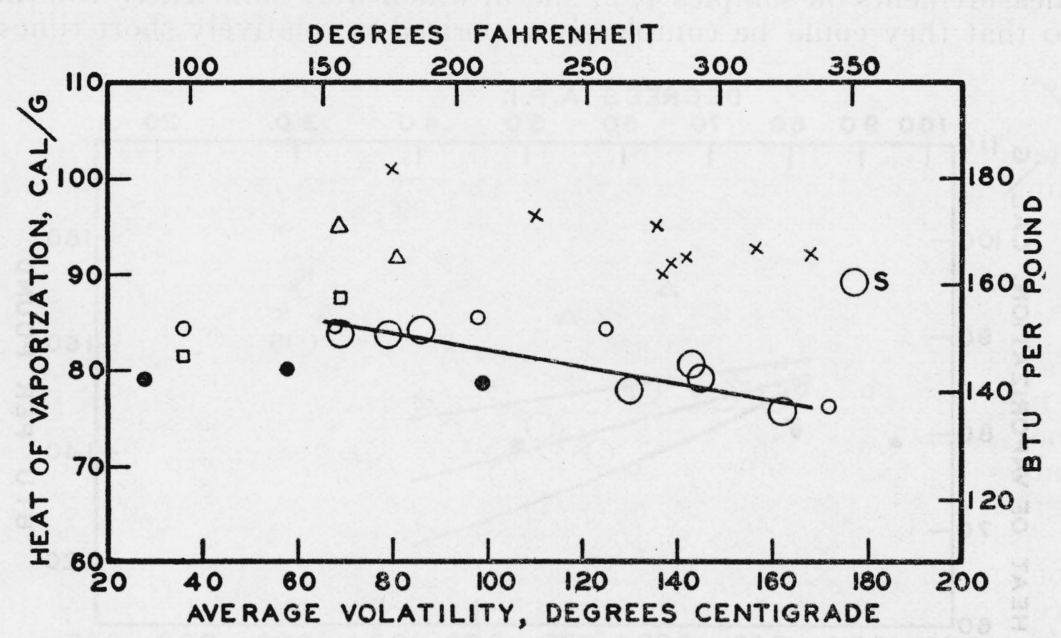

Figure 3.-Heat of vaporization at $40^{\circ} \mathrm{C}$ plotted against "average volatility."

$\begin{aligned} \bigcirc & =\text { Fuels. } \mathrm{S}=\text { Safety fuel. } \\ \mathrm{O} & =\text { Normal paraffins. } \\ & =\text { Isoparaffins. }\end{aligned}$

$\square=$ Olefins.
$\triangle=$ Naphthenes.
$\mathrm{X}=$ Aromatics.

within the accuracy of the measurements, by a linear function of either specific gravity or average volatility. The average deviation of the observed values from the straight line in figure 3 is somewhat less than from the straight line in figure 2 , while the maximum deviation, excepting that for the safety fuel, is somewhat less than 3 percent in both cases.

Curve 1 in figure 2 represents data calculated by means of an equation given by Cragoe ${ }^{4}$ for the heats of vaporization of petroleum distillates. Curve 2 represents data calculated by means of equations given by Weir and Eaton ${ }^{8}$ for the heat contents of petroleum distillates in the liquid and vapor states.

The values for the heats of vaporization of pure compounds shown in figures 2 and 3 were taken in part from International Critical Tables, ${ }^{9}$ and in part from calculations by Young ${ }^{10}$ by means of the Clapeyron equation. Where data were found only at temperatures other than $40^{\circ} \mathrm{C}$, the reduction to $40^{\circ} \mathrm{C}$ was made, if sufficient data

4 Misc. Pub. BS 97 (1929).

8 Ind Eng. Chem. 24, 211 (1932)

Int. Crit. Tables 5, 136.

10 Sci. Proc. Roy. Dublin Soc. 12, 374 (1910). 
were available, by the method described by Perry and Smith. ${ }^{11}$ If sufficient data to use this method were not available, the reduction to $40^{\circ} \mathrm{C}$ for paraffin hydrocarbons was made using the relation

$$
\frac{d L}{d t}=-\frac{0.09}{d}
$$

where $L$ is heat of vaporization, $t$ is temperature, and $d$ is specific gravity at $15^{\circ} \mathrm{C}$ (or $60^{\circ} \mathrm{F}$ ) referred to water at the same temperature as unity. This relation was obtained by differentiating Cragoe's equation ${ }^{12}$ for the heats of vaporization of petroleum distillates. For the aromatic hydrocarbons a similar relation was used, namely,

$$
\frac{d L}{d t}=-\frac{0.13}{d}
$$

the constant, 0.13 , being deduced from the data on benzene by Fiock, Ginnings, and Holton. ${ }^{13}$ For the remaining compounds the relation

$$
\frac{d L}{d t}=-\frac{0.1}{d}
$$

was used. Equation 2 for paraffin hydrocarbons was checked for a number of these compounds, and eq 3 for aromatic compounds was checked for toluene by the method of Perry and Smith. ${ }^{11}$ The values of heat of vaporization at $40^{\circ} \mathrm{C}$ obtained by the two methods agreed in general within 2 percent.

As proposed by Cragoe and Hill, ${ }^{14}$ gasolines may be divided for convenience into two classes on a volatility basis. These two classes are aviation gasolines with average volatilities ranging from 80 to $110^{\circ} \mathrm{C}\left(176\right.$ to $\left.230^{\circ} \mathrm{F}\right)$, and motor gasolines with average volatilities ranging from 110 to $140^{\circ} \mathrm{C}\left(230\right.$ to $\left.284^{\circ} \mathrm{F}\right)$. The variation of heat of vaporization with volatility indicated by the curve of figure 3 is so small that within the accuracy with which the correlation with volatility is valid, the average heat of vaporization for each class of gasolines may be taken as the heat of vaporization of any gasoline in that class. In table 5 are given the average heats of vaporization of aviation and motor gasolines at various temperatures calculated from the heats of vaporization at $104^{\circ} \mathrm{F}$ by means of eq 2 , and heats of vaporization of the safety fuel at various temperatures calculated from the observed heat of vaporization at $104^{\circ} \mathrm{F}$ by means of eq 3 . The values in this table for temperatures other than $100^{\circ} \mathrm{F}$ are given in parentheses to emphasize the fact that they are calculated, and are therefore not as reliable as the values at $100^{\circ} \mathrm{F}$, which are based on observed data.

\footnotetext{
11 Ind. Eng. Chem. 25, 195 (1933).

12 Misc. Pub. BS 97 (1929).

13 BS J. Research 6, 881 (1931) RP312.

14 BS J. Research 7, 1133 (1931) RP393.
} 
TABLE 5.-Heats of vaporization of gasolines

\begin{tabular}{|c|c|c|c|}
\hline \multirow{4}{*}{$\begin{array}{l}\text { Tempera- } \\
\text { ture }\end{array}$} & \multicolumn{3}{|c|}{ Heat of vaporization } \\
\hline & $\begin{array}{l}\text { Aviation } \\
\text { gasoline }\end{array}$ & $\begin{array}{l}\text { Motor } \\
\text { gasoline }\end{array}$ & $\begin{array}{l}\text { Safety } \\
\text { fuel }\end{array}$ \\
\hline & \multicolumn{3}{|c|}{ "Average volatility" } \\
\hline & $\begin{array}{l}80 \text { to } 110^{\circ} \mathrm{C} \\
\left(176 \text { to } 230^{\circ} \mathrm{F}\right)\end{array}$ & $\begin{array}{l}110 \text { to } 140^{\circ} \mathrm{C} \\
\left(230 \text { to } 284^{\circ} \mathrm{F}\right)\end{array}$ & $\begin{array}{l}177^{\circ} \mathrm{C} \\
\left(351^{\circ} \mathrm{F}\right)\end{array}$ \\
\hline $\begin{array}{c}{ }^{\circ} \mathrm{F} \\
0 \\
50 \\
100 \\
150 \\
200 \\
250 \\
300 \\
350 \\
400 \\
450 \\
\end{array}$ & $\begin{array}{c}\mathrm{Btu} / \mathrm{lb} \\
(161) \\
(155) \\
148 \\
(142) \\
(136) \\
(130) \\
(123)\end{array}$ & $\begin{array}{c}\mathrm{Btu} / \mathrm{lb} \\
(157) \\
(151) \\
145 \\
(138) \\
(132) \\
(126) \\
(120) \\
(114)\end{array}$ & $\begin{array}{r}\text { Btu/lb } \\
(176) \\
(169) \\
161 \\
(154) \\
(146) \\
(139) \\
(131) \\
(124) \\
(116) \\
(109)\end{array}$ \\
\hline
\end{tabular}

In view of the small range covered by the heats of vaporization of the various fuels, it seems probable that appreciable differences in the tendency toward ice formation in the carburetor with different fuels must be due largely to differences in the completeness of vaporization resulting from differences in volatility. The more volatile a fuel the more completely it will be vaporized in the carburetor under given conditions, and the greater will be the heat absorbed per pound of fuel. For example, according to Allen, Rodgers, and Brooks, ${ }^{15}$ with an air-fuel ratio of 12 , a fuel having an average volatility of $87^{\circ} \mathrm{C}$ will be 78 percent evaporated in the carburetor at $0^{\circ} \mathrm{C}$, while a fuel having an average volatility of $101^{\circ} \mathrm{C}$ will be only 55 percent evaporated at $0^{\circ} \mathrm{C}$. Hence, assuming that the two fuels have about the same heat of vaporization, the more volatile fuel will absorb 42 percent more heat per pound than the less volatile one.

In conclusion the author desires to acknowledge his indebtedness to H. C. Dickinson and C. S. Cragoe for valuable advice during the course of the work. The specific gravities and distillation data on the fuels were determined by H. S. White. The refractive indices were measured by J. D. White. The chemical tests of the safety fuel were made by J. D. White, R. T. Leslie, and F. W. Rose.

Washington, June 18, 1935.

$11^{5}$ Soc. Automotive Engrs. J. 35, 417 (1934): 